\title{
Determinants Of Liquidity Risk In Banking Sector On The Indonesia Stock Exchange
}

\author{
Susy Muchtar and Gianvha Sena Rustimulya \\ Faculty of Economy and Bussiness Trisakti University \\ Email:Susy.muchtar@gmail.com,gianvhasena@gmail.com
}

\begin{abstract}
This research aims to determine the factors that impact liquidity risk. The sample used in this research is a banking sector that is listed on the Indonesia Stock Exchange (IDX) in the period 2008-2017. Independent variable in this research bank size, deposits, profitability, cost of funds, asset quality, capital adequacy ratio, economic cycle, and inflation and the dependent variable is liquidity risk. The amount of the sample of the research amounted to 25 banking sector, by using purposive sampling. The result of this research indicates that bank size, profitability, cost of funds, and asset quality have a negative effect on liquidity risk, while deposits, capital adequacy ratio, economic cycle, and inflation have no impact on liquidity risk. The results of this study are expected to be used as a reference for bank managers and investors in looking at the factors that affect the liquidity risk in the banking industry.
\end{abstract}

Keywords: asset quality, capital adequacy ratio, economic cycle, inflation, liquidity risk and profitability.

\section{INTRODUCTION}

As banks have become one of the most vital components of any financial system, ensuring the stability of the banking sector has gained significant importance as a policy initiative worldwide. Banking stability as an economic indicator can be used to determine whether an economy is robust enough to withstand both the internal and external shocks. Banking stability in itself is a function of several health parameters of individual banks, e.g., asset quality, liquidity risk, capital adequacy, performance, etc. (Reserve Bank of India, 2013). Among the banking stability parameters, discussions and research on the liquidity risk component have gathered momentum following the aftermath of the financial crisis of 2008, during which the banks were faced with severe liquidity crunch (Vodova, 2011; Choon et al., 2013). Moreover, the Basel Committee on banking supervision emphasized that the stability of a commercial bank depends on its liquidity position and effective liquidity risk management (Bank for International Settlements, 2009).

The performance of a bank can be considered effective if it has good liquidity risk management. Liquidity risk is a major factor that must be considered by the bank. Liquidity risk is the inability of banks to fulfill obligations (Reserve Bank of India, 2012). The inability of banks to meet their obligations arises because banks cannot fulfill their liquid assets. As a result, banks will have liquidity problems. In the event of a liquidity problem, public confidence in the bank's performance begins to decline and then starting to withdraw 
funds in the bank at the same time. So the bank suffered a loss which affects the bankruptcy (Sopan and Dutta, 2018).

Liquidity risk has increased quite widely because it can cause a financial crisis that occurs globally (Langley, 2010). The financial crisis resulted in a decline in asset prices. When the financial crisis occurs, banks try to overcome liquidity problems by changing their assets to become more liquid so that banks can meet their short-term obligations. But in the end, the impact of the decline in asset prices is generally caused by the excess inventory of bank assets that are not followed by increased demand (Langley, 2010). Therefore, the Basel Committee on banking supervision sets general requirements for banks to have a minimum amount of capital of the bank which is $8 \%$ to avoid bankruptcy risk (Bank for International Settlements, 2013).

Effective liquidity risk management is essential for each bank to help ensure the bank's ability to meet its liquid assets and reduce the possibility of liquidity risk (Sopan and Dutta, 2018). This is increasingly important since liquidity risk in the banking sector can influence the performance of a bank in developing countries, where the bank will act as the dominant financial intermediary. In Indonesia, Bank Indonesia has issued a Regulation on the Capital Adequacy Ratio (CAR) regulated in Bank Indonesia Regulation number 15/12/PBI/2013 which reads that each bank is required to provide a minimum capital according to a risk profile a minimum of $8 \%$ (Bank Indonesia, 2013).

A number of studies have conducted research on factors that influence liquidity risk. Factors that influence liquidity risk are bank specification variables including bank size, deposits, profitability, cost of funds, asset quality, capital adequacy ratio (Sopan and Dutta, 2018). Bank size is the size of a bank that is seen from the value of the total net assets of the bank (Choon et all., 2013). Bank size has a positive influence on liquidity risk at banks in Europe (Cucinelli, 2013). Banks that have high total assets tend to avoid liquidity risk. In addition to having adequate assets, banks should also pay attention to the source of funding used to generate income, that is deposits (Menicucci and Paolucci, 2016). Whereas there is a positive influence between deposits and liquidity risk where if the demand for deposits increases, it will affect the level of ownership on liquidity assets (Bonner et al., 2014).

Companies that have high-income levels are usually able to carry out their business activities. It tends to make the company avoid the risk of liquidity. The level of income can be called also with profitability. Profitability had a negative effect on liquidity risk (Delechat et al., 2014), The following variables can affect the liquidity of banks in Romania include the cost income ratio, credit risk and the cost of funds rate (Munteanu, 2012), He also found that capital, credit, interbank funding costs, and interest rates will negatively affect bank liquidity. In addition to the level of deposits, cost of funds was also found to have a negative relationship with the liquidity of banks, which resulted in increased liquidity risk of banks in India (Sopan and Dutta, 2018). Asset quality is used to assess the types of assets held by banks (Kasmir, 2015). The research states that asset quality has a significant relationship with liquidity risk (Sopan and Dutta, 2018). Capital adequacy ratio is the amount of capital must be owned by a bank or other financial institution as required by the financial regulator (Ogege et all., 2012). Bank capital has a negative impact on bank liquidity (Lei and Song, 2013), Banks can avoid liquidity risks by increasing their capital that the bank's capital structure to be better.

The other factors that affect liquidity risk are macroeconomic factors such as inflation and economic cycle. Research on the banks in India, it was found that the rate of inflation 
has a negative influence on bank liquidity (Bhati et al., 2015). There are also other studies of bank liquidity and inflation. According to the study, inflation had a positive impact on liquidity (Tseganesh, 2012). Economic Cycle is measured by using the Gross Domestic Product (GDP) (Sopan and Dutta, 2018). GDP is an indicator of state financial health (Choon et al., 2013). Gross Domestic Product (GDP) has a positive influence on Liquidity Risk (Choon et al., 2013).

Restricting the problem. This study has several limitations issues discussed were the following things: (1) Companies are examined in this study is the banking sector listed in Indonesia Stock Exchange during the period 2008-2017. (2) Companies in the Banking Sector published the Annual Financial Statements (Annual Report) complete during the period 2008-2017. (3) Companies in the banking sector have the components required for variables studied were is the bank size, deposits, profitability, cost of funds, asset quality, capital adequacy ratio, economic cycle, and inflation. (4) The Company did not experience any delisting in the period 2008-2017.

\section{THEORETICAL REVIEW}

Liquidity Risk. Liquidity risk is a risk where the bank is unable to meet the liquid assets owned by the bank. A bank can be said to be liquid if the bank has a payment instrument in the form of current assets that is greater than its obligations (Sopan and Dutta, 2018). Banks are unable to fulfill their liquid assets usually occur because banks have assets that cannot be disbursed such as bad credit. This is caused because the credit borrower is unable to return the funds borrowed so that banks are not able to channel these funds back to the depositor This can result in banks losing trust from the public because banks cannot properly manage their liquid assets. Then they will start to withdraw funds continuously and if it occurs on a large scale or also called the bank rush, then the bank can have liquidity problems.

Bank Size. Bank size is a measure that indicates the size of a bank (Al-Kuwari, 2009). The size of a bank can be seen from the total assets. The greater the assets owned by a bank, the greater the size of the bank. Banks that have a high number of assets may cause the bank is exposed to liquidity risk. This causes the creation of different liquidity in each bank according to the size of the bank. The research states that bank size has a positive effect on the liquidity ratio (Deléchat et all., 2014). In addition, there are also those who argue that smaller banks tend to have smaller liquidity assets (Rauch et all., 2010; Berger and Bouwman, 2009).

Deposits. Deposits are the main source of bank funding. The main source of funding banks is savings deposits, demand deposits, and deposits (Anbar and Alper, 2011). Banks as financial institutions raise funds from the public and distributed these funds to borrowers in the form of loans (Al-Khouri, 2012). The bank's activities led to the bank may be exposed to liquidity risk. It can happen because if the majority of depositors requesting funds kept but the bank can not fulfill depositors' funds due to bank loans being disrupted, causing banks to lack liquidity. This lack of liquidity can result in the bank being unable to fulfill all its obligations (Vodova, 2011). 
Profitability. Profitability is the ability to generate profits from all the business activities of an organization or company (Olalekan and Adeyinka, 2013). In a study on bank profitability and liquidity risk show that the higher the profitability of a bank, the higher the risk of liquidity (Parameswar and Murthy, 2012), As other studies have also found that there is a significant positive effect between profitability and liquidity risk (Sudirman, 2015). This is because profitability is one source of liquidity creation. The greater the bank's profitability, the greater the ability of banks to meet liquidity needs.

Cost Of Funds. Cost of funds is the cost to be incurred by the bank for any funds that have been collected from various sources before deducting statutory liquidity set by the government (Kasmir, 2015). The cost of funds will be determined from how much interest established to raise funds through public deposits. The greater interest charged to the higher cost of funds. Cost of funds has a positive impact on liquidity risk. The higher the interest expense incurred higher liquidity risk (Munteanu, 2012). Since banks with a larger funding cost are likely to have substantial funds from the public. Then, with the deposits of the depositors, the bank will distribute the funds back to the public in the form of loans. So will cause the number of bank assets also increased. This will lead to liquidity risk if banks are not able to manage their liquid assets well.

Asset Quality. Asset quality is the bank's ability to manage the assets which are a source of bank revenue to finance the operations of the bank (Menicucci and Paolucci, 2016). Asset quality is a component to measure the financial strength of a bank, because the quality of assets associated with the left side of bank balance sheets, the side in which the bank allocates resources for lending to the borrower and the loan is a source of bank revenue. So that management must pay attention to loans granted to borrowers (Gadhia, 2015). Asset quality in the banking system linked to the quality of loans granted by banks. Thus, the loan quality can be assessed loans (non-performing loans) (Said, 2018).

Capital Adequacy Ratio. Capital adequacy ratio is the ratio used to assess capital adequacy, and assess the health of commercial banks because it represents how well the financial system in a bank (Menicucci and Paolucci, 2016). Thus, the capital adequacy ratio is also widely used to analyze the status of a bank's financial strength. Especially in developing countries, a strong capital structure is very important for financial institutions. Banks with weak capital structure can hardly face the risk of liquidity. Therefore, it is important for financial institutions to maintain the strength of the higher capital structure to bear the losses in the future and ignore the risk of bankruptcy during hard times (Menicucci and Paolucci, 2016).

Economic Cycle. The economic cycle is the fluctuation of the level of economic activity (GDP) between periods of expansion (growth) and periods of depression. The economic cycle has four phases, that is expansion, boom, recession, depression (Yulita and Pangestuti, 2014). At the expansion stage, an increase in aggregate demand will cause an increase in loan growth in the banking sector to carry out its operational activities (Alper et al., 2012). After that, at the boom stage, banks will be more confident in getting profits by expanding loan funds to maintain the economic situation and limit funds in times of an economic downturn to prioritize liquidity (Painceira, 2010). 
In the recession stage, banks will experience an increase in the number of bad loans due to borrowers being unable to repay loans when due and causing banks to experience liquidity shortages. This will make the community lose confidence in the bank and withdraw the funds it collects (Painceira, 2010). Furthermore, during the depressive stage, there was a massive sale of bank assets because the bank was unable to fulfill its obligations to depositors. This will make the bank face a bank rush where depositors will withdraw the funds collected at the same time and cause the bank to go bankrupt (Sudirman, 2015).

Factors that can be used to determine the stage of the economic cycle is currently the Gross Domestic Product (GDP). Gross Domestic Product (GDP) is the total market value of all final goods and services produced in a country in a given time (Alper et all., 2012). Gross Domestic Product (GDP) can be regarded as a health measure of a country and is also used as an indicator of the business cycle (Al-Harbi, 2017). The study found a positive correlation between GDP growth and liquidity risk (Vodová, 2013).

Inflation. Inflation is the event of price increases that occur continuously. The asymmetric information theory explained that the increased rate of inflation may reduce the return on the assets that lead to credit rationing and then will increase bank liquidity (Fola, 2015). On the other hand, as for the research which found a negative relationship between inflation and liquidity risk (Trenca et all., 2015). It explains that a high inflation rate will reduce the loan rate because when interest rate inflation rises, it causes liquidity to be lower (Trenca et all., 2015).

Conceptual Framework. Banks that have a good operating system will have a way to calculate the liquidity risk that will be faced in the future. To know that, the bank needs to consider some important factors of the (internal) or outside (external). Internal factors that can affect a bank's liquidity risk is bank-specific size determinant that includes banks, deposits, profitability, cost of funds, asset quality and capital adequacy ratio that affect liquidity risk (Sopan and Dutta, 2018). In addition to internal factors, there is also the influence of external factors, namely banks macroeconomic determinants include the economic cycle and inflation (Sopan and Dutta, 2018). The importance of internal and external factors made a number of studies conduct research on determinants of liquidity risk at banks.

Research carried out in Italy in 675 samples in the bank shows the results of that bank size has a negative effect on the liquidity risk (Giannotti et all., 2010). The larger banks have lower liquidity risk. In a subsequent study looked at the relationship between the level of deposits and liquidity risk. The results suggest that the level of deposits in the bank positively affect liquidity risk (Singh and Sharma, 2016). The greater the level of deposits a bank, the greater the risk of liquidity. That is because if depositors keep their funds in the bank the amount will be used by the bank to provide loans to the borrowers. If the borrower can not repay the loan, the bank can not fulfill the rights of depositors when depositors want to withdraw their funds in the bank, so that it will lead to an increased risk of bank liquidity.

Other research conducted research on 43 commercial banks operating in the GCC countries during 1998-2008 to examine the profitability variable. The results of these studies explain that there is a negative relationship between profitability and liquidity risk (AlKhouri, 2012). This is because the banks are not able to regain the impact of liquidity costs i.e. interest income on bank loan will lower the level of profitability. While subsequent 
studies looked at the relationship between the cost of funds and liquidity risk (Choon et al., 2013). The results showed that the negative correlation between the cost of funds to the liquidity risk.

Then, the researchers conducted a study of asset quality as measured by impaired loans and compared to gross loans. The results of his research state that there is a negative relationship between asset quality and liquidity risk (Munteanu, 2012). This is because the bank has good asset quality can avoid the risk of liquidity if banks are able to regulate their liquidity efficiently. Research in a study with 22 banks during the period 2006-2009, emphasizing explanations about the determinants of liquidity risk. The results show that the liquidity ratio of banks in the Czech Republic has a positive effect on the capital adequacy ratio. Because the greater the capital structure owned by the bank, the higher the risk of liquidity held by banks (Vodova, 2011).

Subsequent research conducting a study of 59 commercial banks in India during the period 2000-2013. The results show that inflation would have a significant positive effect on liquidity risk (Singh and Sharma, 2016). While the Gross Domestic Product (GDP) has a negative influence on liquidity risk (Singh and Sharma, 2016). However, it has also been found that the Gross Domestic Product (GDP) has a positive influence on liquidity risk. This is because the bank has a good performance will regulate liquidity by either (Choon et al., 2013). Therefore, when the economy is in a state is good, the people will have a better income and start saving some of their income in the bank. So the banks have a funding source that can be used for operational activities and provide loans to the public. Based on the theoretical explanation conducted previous research, the conceptual framework of this research can be described as follows:

Figure 1. Conceptual framework

\section{Independent variables}

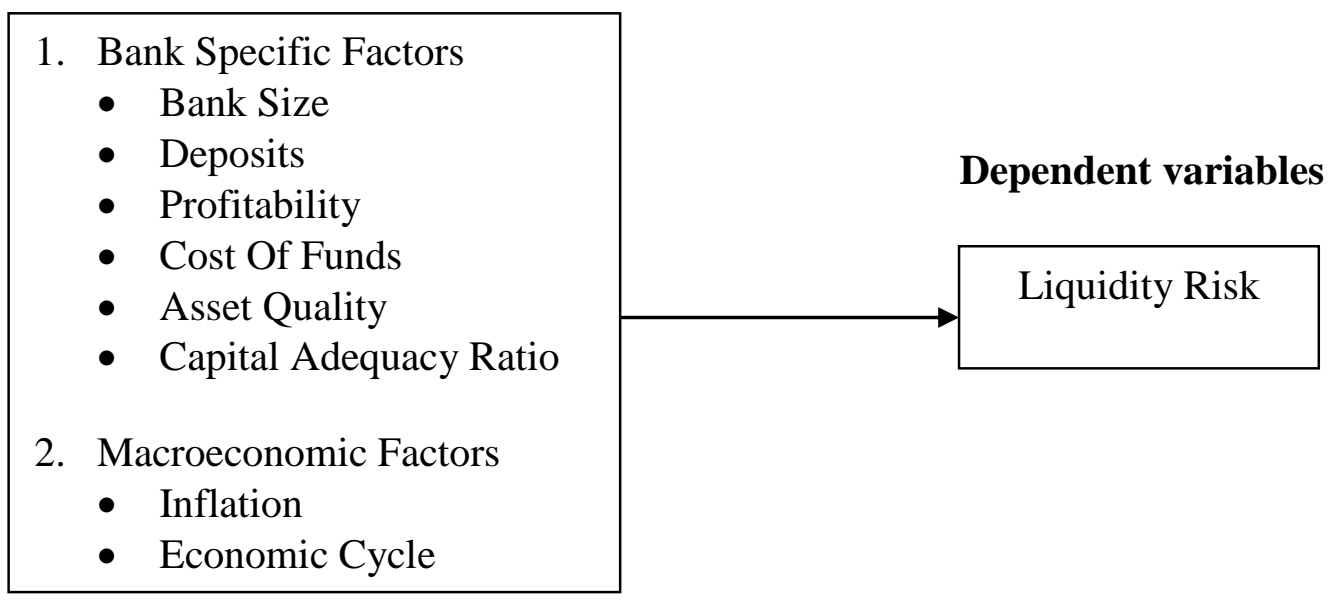

\section{Hypothesis Development}

The effect of bank size to liquidity risk. The size of the bank in terms of total assets has a positive and significant impact on liquidity (Dinger, 2009). Similarly, other research explains that there is a significant and negative effect of bank size to liquidity risk (Choon et al., 2013; Delechat et al., 2014; Singh and Sharma, 2016). Subsequent studies were conducted in banks in Europe and North America in the period 2002-2009. In these studies 
illustrate how banks can manage liquidity risk. The results suggest that the size of banks generally have a positive impact on bank liquidity (Bonfim and Kim, 2011). In addition, it was also found that larger banks had lower liquidity risk in the sample of 675 banks in Italy (Giannotti et al., 2010). Based on previous research, the hypothesis of this study can be formulated as follows:

H1: There is influence between bank size to liquidity risk.

The effect of deposits to liquidity risk. The level of deposits in banks can positively affect their liquidity risk (Singh and Sharma, 2016). Similarly, there is a negative relationship between deposit rates and liquidity risk in European banks (Dinger, 2009). Other studies argue that there is a positive influence between deposits on bank liquidity risk (Bonner et al., 2014). In addition, there are also those who argue that banks face liquidity problems when deposits in banks are unexpectedly withdrawn (Arif and Anees, 2012). Based on previous research, the hypothesis of this study can be formulated as follows:

H2: There is influence between deposits to liquidity risk.

The effect of profitability on liquidity risk. Banks are faced with the difficulty of being liquid and profitable. This results in some of the theories in the study to explain the effect on the profitability of the liquidity risk. Inability to regain the impact of liquidity costs i.e. interest income on bank loan leads to reduced levels of profitability, which showed a negative relationship between profitability and liquidity risk (Delechat et all., 2014; AlKhouri, 2012). On the other hand, there is a positive relationship between profitability and liquidity risk, where banks will get greater profits if they have adequate liquid assets (Bordeleau and Graham, 2010). The results of other studies indicate that there is a positive relationship between profitability and liquidity risk (Wojcik-Mazur and Szajt, 2015).

The level of bank profitability can influence the level of liquidity risk and has been found to have a negative relationship (Sudirman, 2015), This is reinforced by the findings of research on the determinants of liquidity risk of banks in Tunisia (Moussa, 2015). However, there is also a positive correlation of profitability in liquidity risk at banks in India and Ghana (Singh and Sharma, 2016; Lartey et all., 2013). Subsequent research to study the factors that affect the risk of bank liquidity. The research results showed that the size of the bank, profitability, and the monetary policy interest rate is negatively related to bank liquidity (Rauch et al., 2010). Based on previous research, the hypothesis of this study can be formulated as follows:

H3: There is influence between profitability to liquidity risk.

The effect of the cost of funds to liquidity risk. The negative correlation of funding costs with bank liquidity has found several studies in their studies of banks in Tunisia, Malaysia and Czech (Moussa, 2015; Choon et al, 2013; Vodova, 2011). Funding costs measured by total interest expense divided by total liabilities can positively affect bank liquidity risk (Munteanu, 2012). This explains that the higher the funding costs incurred by the bank, the higher the liquidity risk. Meanwhile, funding costs were found to have a positive relationship with bank liquidity risk (Dinger, 2009). Based on previous research, the hypothesis of this study can be formulated as follows:

H4: There is an influence between the cost of funds to liquidity risk. 
The effect of asset quality to liquidity risk. The level of non-performing loans to total advances owned by banks will adversely affect the quality of assets and also have an impact on the overall revenue generation capacity, which in turn affects their liquidity risk (Delechat et al., 2014). Asset quality as measured by non-performing loans compared to gross loans and negatively affects the liquidity risk. (Sudirman, 2015; Moussa, 2015; Vodova, 2013; Munteanu, 2012), Another study found that the liquidity risk of banks in the Euro Zone can be positively affected by asset quality (Cucinelli, 2013). Based on previous research, the hypothesis of this study can be formulated as follows:

H5: There is an influence between the asset quality of liquidity risk.

The effect of capital adequacy to liquidity risk. Research on liquidity risk banks in Europe provides evidence that the capital adequacy ratio has a positive impact on banks' liquidity risk (Vodova, 2011 \& 2013; Cuccinelli, 2013; Dinger, 2009). The research by (Singh and Sharma, 2016) on the determinants of liquidity risk reinforces the findings of research on banks in Europe, but research on banks in Southeast Asia to support their negative relationship between capital adequacy ratio to liquidity risk (Sudirman, 2015; Choon et al., 2013).

A study of 22 banks during the period 2006-2009, emphasized the determinants of liquidity risk is measured by the balance of the different indices (Vodova, 2011). The results show that the liquidity risk of banks in the Czech Republic is higher when it has a capital adequacy ratio that is higher when interest rates are also higher. Banks with capital adequacy that is better able to present a risk of lower liquidity (Bonfim and Kim, 2011). Based on previous research, the hypothesis of this study can be formulated as follows:

H6: There is influence between capital adequacy to liquidity risk.

The effect of the economic cycle to liquidity risk. The influence of the growth of Gross Domestic Product (GDP) in the bank's liquidity risk can also vary depending on the nature of the economy and the level of financial intermediation role of the banking sector in the economy. In most of the studies related to the determinants of bank liquidity risk, it has been found that the rate of GDP growth has a positive effect on the level of bank liquidity risk (Choon et al., 2013; Sudirman, 2015. Moussa, 2015; Vodova, 2013). However, there is also a negative correlation between liquidity in European banks (Dinger, 2009) and a similar relationship is also observed in banks in India, where GDP has a negative relationship with liquidity risk (Singh and Sharma, 2016).

On the other hand, a study conducted in the countries of the Visegrad finds a positive relationship between GDP growth and liquidity risk (Vodova, 2013). This is because businesses need time to collect profits and savings before reducing their proportion of external financing which will result in higher bank liquidity. Based on previous research, the hypothesis of this study can be formulated as follows:

H7: There is influence between economic cycle to liquidity risk.

The effect of inflation on liquidity risk. The inflation rate and the growth rate of GDP is one of the determining factors that can affect liquidity risk (Delechat et al., 2014). Inflation can be a negative or positive impact on the liquidity of banks due to various studies. Inflation is found to have a negative relationship to liquidity risk (Vodova 2011; Cucinelli, 2013). Meanwhile, other studies found a positive relationship between inflation and liquidity risk 
(Sudirman, 2015; Singh and Sharma, 2016). Furthermore, in the study of the liquidity risk of banks in Romania found that inflation is negatively affected by liquidity risk during the years 2002-2007 while inflation had a positive impact on the liquidity risk in the next year i.e. 2008-2010 (Munteanu, 2012). Based on previous research, the hypothesis of this study can be formulated as follows:

H8: There is influence between inflation to liquidity risk.

\section{METHODOLOGY}

Research design. The research design used in this study is the method of hypothesis testing for this study was conducted to determine the effect of independent variables bank-specific determinants that bank size, deposits, profitability, cost of funds, asset quality, capital adequacy ratio and macroeconomic determinants, namely the economic cycle, and inflation on the dependent variable, namely liquidity risk. The method of analysis in this study using panel data regression analysis. This study analyzes the commercial banks during the period 2008 - 2017 and has been listed on the Indonesia Stock Exchange. The analytical tool used is the data panel regression with Eviews 9.0 software.

\section{Variables and Measurement}

Dependent variables. The dependent variable in this study is the Liquidity Risk. These variables can be measured using the following formulation:

$$
\text { Liquidity Risk }=\frac{\text { Total Liquid Assets }}{\text { Total Assets }}
$$

Source: (Sopan and Dutta, 2018)

Independent variables. Independent variables in this study are bank-specific size determinant include banks, deposits, profitability, cost of funds, asset quality and capital adequacy, as well as the macroeconomic determinants, are economic cycles and inflation.

\section{Bank Size}

Bank Size can be measured using the following formulation:

$$
\text { Bank Size = Logarithma Natural of Total Asset }
$$

Source: (Sopan and Dutta, 2018)

Deposits

Deposits can be measured using the following formulation:

$$
\text { Deposits }=\frac{\text { Deposits }}{\text { Total Liabilities }} \times 100
$$

Source: (Sopan and Dutta, 2018)

Profitability

Profitability can be measured using the following formulation: 


$$
\text { Profitability }=\frac{(\text { Interest Earned }- \text { Interest Expended })}{\text { Average }(\text { total assets })} \times 100
$$

Source: (Sopan and Dutta, 2018)

Cost Of Funds

Cost Of Funds can be measured using the following formulation:

$$
\text { Cost Of Funds }=\frac{\text { (Interest Expended })}{\text { Average }(\text { Deposits }+ \text { Borrowings })} \times 100
$$

Source: (Sopan and Dutta, 2018)

Asset Quality

Asset Quality can be measured using the following formulation:

$$
\text { Asset Quality }=\frac{\text { Impaired Loans }}{\text { Gross Loans }}
$$

Source: (Munteanu, 2012)

Capital Adequacy Ratio

Capital Adequacy Ratio can is measured using the following formulation:

Capital Adequacy Ratio = Capital Adequacy Ratio Tier 1

Source: (Sopan and Dutta, 2018)

Economic Cycle

Economic Cycle can be measured using the following formulation:

Economic Cycle $=$ Gross Domestic Product (GDP) Growth Rate

Source: (Sopan and Dutta, 2018)

Inflation

Inflation can be measured using the following formulation:

$$
\text { Inflation }=\text { Consumer Price Index (CPI) Inflation Rate }
$$

Source: (Sopan and Dutta, 2018)

Method of collecting data. The data used in this research is secondary data. Secondary data is data obtained indirectly researchers from the work of others or sources have been published so that the data is available. The data collected are the financial statements (annual report and the financial report) sector of the banking industry have been published and listed on the Indonesia Stock Exchange (BEI) in the period 2008 - 2017. The financial statement data obtained from the website of the Indonesia Stock Exchange (IDX) is www. idx.co.id and Central Bureau of Statistics Republic of Indonesia (BPS) is www.bps.co.id

Data Testing Methods. Methods of testing data used in this study is a data panel regression, which aims to test and analyze the effect of bank size, deposits, profitability, cost of funds, 
asset quality, capital adequacy ratio, the economic cycle, and inflation of the liquidity risk in the banking industry listed on the Indonesia Stock Exchange (BEI). The available data is then processed and tested using 9.0 eviews software.

\section{THE RESULTS OF STATISTICAL TESTS}

Test Model. Panel data regression analysis can be analyzed using three models: a model common effect (pooled least square), fixed effect and random effect. To determine the model was good and right in order to interpret, there are two stages of testing that must be done test Chow and Hausman test, as follows:

Figure 2. Scheme Selection Panel Data Regression Model

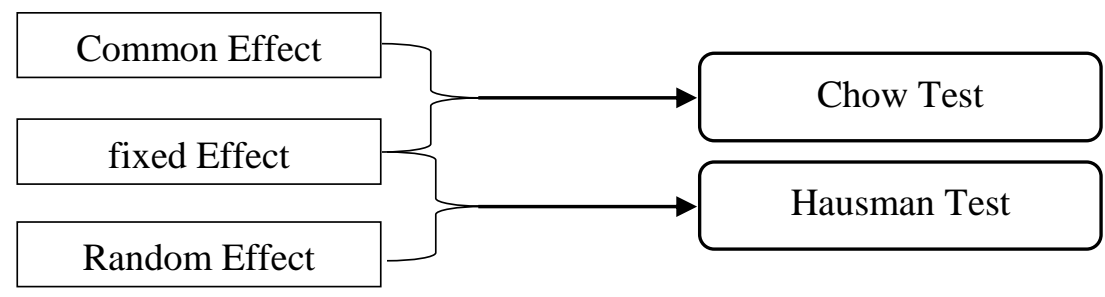

In this model the Chow test is used to select a common method or Fixed Effect Effect, then use the Hausman test to choose a model Fixed Effect or Random Effect. The test measures a panel data is as follows:

Chow Test. Chow test is the test used to select appropriate models used in the study, namely the Common models or model Fixed Effect Effect. In tests carried out by the Chow test the following hypotheses:

$\mathrm{H}_{0}$ : a more appropriate model is the Common Effect.

Ha: A more accurate model Fixed Effect.

The decision-making criteria, namely:

- If prob. Cross section of the chi-square $<\alpha 0.05, \mathrm{H} 0$ is rejected.

- If prob. Cross section of the chi-square> $0.05, \mathrm{H} 0$ is accepted.

Table 1. Chow Test Results

\begin{tabular}{c|c|c|c}
\hline Variables & Chi-Square & Prob & Decision \\
\hline Liquidity Risk & 256.517706 & 0.0000 & $\begin{array}{c}\mathrm{H}_{0} \text { is rejected, the fixed effect } \\
\text { model chosen }\end{array}$ \\
\hline
\end{tabular}

Source: (Output Data Eviews 9.0, 2019)

According to the table 1, chow test results showed that the probability of CrossSection of Chi-Square LIQTA $0.0000<0.05$ then the decision obtained by the H0 is rejected so that the model used is the Fixed Effect. If the selected model is a model of fixed effect, it is necessary to test the fixed effect model with a random effect that the Hausman test. 


\section{a. Hausman Test}

Hausman test is a test used to select the best model among models or model Fixed Effect Random Effect. Hausman test can also be used to look at the models that have heterogeneity in the characteristics of each model will be used between the Fixed Effects and Random Effect. Hausman test is done by using the following hypotheses:

$\mathrm{H}_{0}$ : The right model is Random Effect (There is interference between individuals).

Ha: The right model is fixed Effect (No interference between individuals).

The criteria in decision-making:

- If prob. Cross section of the chi-square $<\alpha 0.05$ then $\mathrm{H}_{0}$ rejected.

- If prob. Cross section of the chi-square $>\alpha 0.05$ then $\mathrm{H}_{0}$ be accepted.

Table 2. Hausman Test Results

\begin{tabular}{c|c|c|c}
\hline Variables & Chi-Square & Prob & Decision \\
\hline Liquidity Risk & 0.000000 & 1.0000 & $\begin{array}{c}\mathrm{H}_{0} \text { is accepted, then the Random } \\
\text { Effect Model Selected }\end{array}$ \\
\hline
\end{tabular}

Source: (Output Data Eviews 9.0, 2019)

Based on the result table 2 Hausman test, the results showed that the probability Cross-section Statistics LIQTA at $1.0000>0.05$ then the decision can be obtained by $\mathrm{H} 0$ is accepted that the model used is Random Effect Model.

Simultaneously Test (Test F). F test showed that all independent variables in the model meant having a simultaneous effect on the dependent variable. The hypothesis to be tested are as follows:

$\mathrm{H}_{0}$ : The independent variables together did not affect the dependent variable.

Ha: The independent variables jointly affect the dependent variable.

Criteria for decision-making:

- If sig of $\mathrm{F}$ prob $<0.05$ then $\mathrm{H}_{0}$ is rejected.

- If sig of $\mathrm{F}$ prob $>0.05$ then $\mathrm{H}_{0}$ is accepted.

Table 3. F Test Results

\begin{tabular}{c|c|c|c}
\hline Variables & F-Statistic & Prob & Decision \\
\hline Liquidity Risk & 5.299459 & 0.000004 & $\mathrm{H}_{0}$ is accepted \\
\hline
\end{tabular}

Based on the results of the F test, then the probability of F-statistic LIQTA generates a value of $0.000004<0.05$. Thus the results of the analysis in this study shows that jointly independent variable determinant is bank-specific size banks, deposits, profitability, cost of funds, asset quality, capital adequacy ratio, and macroeconomic determinants are economic cycles, and the inflation effect on the dependent variable, namely liquidity risk so that decent regression model used in this study. 
The goodness of Fit Test (Test Adjusted R2). In this test phase, the overall independent variables in the model are able to show a change of the dependent variables. The R2 is stretched between 0 and $1(0<\mathrm{R} 2>1)$, the independent variables and the dependent variable has increasingly close relationships. The basis for a decision as follows: (1) If the R2 value close to 1 , then the independent variables and the dependent variable has a strong relationship. (2) If the $\mathrm{R} 2$ value approaching 0 , then the independent variables and the dependent variable has a weak relationship.

Table 4. The Goodness Of Fit Test Results

\begin{tabular}{c|c|c}
\hline Variables & R2 & adjusted R2 \\
\hline Liquidity Risk & 0.149599 & 0.121370 \\
\hline
\end{tabular}

Source: (Output Data Eviews 9.0, 2019)

Adj R-Squared $=0.121370=12.1370 \%$

Based on the results of goodness of fit test, the obtained value of adjusted R-squared for LIQTA of 0.121370 , This means that the independent variable determinant is bankspecific size bank, deposits, profitability, cost of funds, asset quality, capital adequacy ratio, and macroeconomic determinants, namely the economic cycle, and inflation is able to explain the variation of the dependent variable is the liquidity risk of $12.1370 \%$ And the balance of $87863 \%$ Clear that the liquidity risk can be affected by other factors that are not included in the model. So that there is a weak correlation between the independent variable determinant is bank-specific size bank, deposits, profitability, cost of funds, asset quality, capital adequacy, and macroeconomic determinants, namely the economic cycle, and inflation on the dependent variable, namely liquidity risk.

\section{Data analysis method}

Multiple Regression Analysis. The analytical method used in this research is multiple regression analysis, which aims to test and analyze the influence of independent variables on the dependent variable. The regression model used in this study are as follows:

$$
\begin{gathered}
\text { LIQTA }_{i t}=\alpha+\beta_{1} L_{N T A_{i t}}+\beta_{2} D T L_{i t}+\beta_{3} N I M_{i t}+\beta_{4} C O F_{i t}+\beta_{5} N P A T A_{i t}+\beta_{6} C A R_{i t} \\
+\beta_{7} G D P_{t}+\beta_{8} I N F_{t}+u_{i}+\epsilon_{i t}
\end{gathered}
$$

$\begin{array}{ll}\text { Information } & \text { : } \\ \alpha & =\text { constant } \\ \text { LIQTA } & =\text { Liquidity Risk } \\ \text { LNTA } & =\text { Bank Size } \\ \text { DTL } & =\text { Deposits } \\ \text { NIM } & =\text { Profitability } \\ \text { COF } & =\text { Cost Of Funds } \\ \text { NPATA } & =\text { Asset Quality } \\ \text { CAR } & =\text { Capital Adequacy } \\ \text { GDP } & =\text { Economic Cycle } \\ \text { INF } & =\text { Inflation } \\ \text { u } & =\text { Bank specific unobserved effect } \\ \varepsilon & =\text { Error }\end{array}$


Test T. T-test was conducted to test whether each - each independent variable has a significant effect on the dependent variable assuming other variables constant. The test is performed with the following hypotheses:

$\mathrm{H}_{0}$ : The independent variable does not affect the dependent variable.

Ha: independent variables affect the dependent variable.

Criteria for decision-making:

- If the $\mathrm{p}$-value $<0.05$ then $\mathrm{H}_{0}$ is rejected, meaning that the independent variables affect the dependent variable.

- If the p-value > 0.05 then $\mathrm{H}_{0}$ is accepted, it means no independent variables affect the dependent variable.

\section{DISCUSSION}

Data Description. Description Data is a brief overview of the data the company used as the object of study in this research. The object of this study is all the industry sectors listed on the Indonesia Stock Exchange on the period 2008-2017 as many as 43 companies. The samples used in this study were 25 companies after a purposive sampling that meet the criteria for 10 consecutive years and publish the complete financial reports.

Descriptive statistics. Descriptive statistics describe the characteristics of the data used in the study were seen from the minimum value, maximum, mean, and standard deviation. The minimum value is the lowest value for each variable, while the maximum value is the highest value for each variable in the study. The mean value is the average value of each variable in the study. The standard deviation of the distribution of research data that is used to reflect data that is heterogeneous or homogeneous fluctuated. Here is the descriptive statistics of the variables used:

Table 5. Descriptive Statistics

\begin{tabular}{l|c|c|c|c|c}
\hline \multicolumn{1}{c|}{ Variables } & N & Mean & Maximum & Minimum & Std. \\
\hline liquidity Risk & 250 & 0.546702 & 0.938177 & 0.199679 & 0.147030 \\
\hline Bank Size & 250 & 31.28341 & 34.65767 & 27.93842 & 1.735321 \\
\hline Deposits & 250 & 0.916248 & 1.056389 & 0.726049 & 0.056798 \\
\hline Profitability & 250 & 0.046914 & 0.124633 & -0.013378 & 0.021005 \\
\hline Cost Of Funds & 250 & 0.113847 & 0.246625 & 0.006138 & 0.036469 \\
\hline asset Quality & 250 & 0.030861 & 0.375854 & 0.000988 & 0.038731 \\
\hline Capital Adequacy Ratio & 250 & 0.157532 & 0.680000 & -0.222900 & 0.071254 \\
\hline Economic Cycle & 250 & 0.055200 & 0.065000 & 0.045000 & 0.006614 \\
\hline Inflation & 250 & 0.055610 & 0.110600 & 0.027800 & 0.027549 \\
\hline
\end{tabular}

Source: (Output Data Eviews 9.0, 2019)

\section{Data analysis}

Multiple Linier Regression. The analytical method used in this study is multiple linier regression with the aim to determine the internal factors that influence the size of banks, deposits, profitability, cost of funds, asset quality, capital adequacy ratio and external 
factors, namely the economic cycle, and inflation to liquidity risk. The regression model used in this study is as follows:

LIQTA $=1.487881-0.024388$ LNTA DTL + $0.116992-2.215732$ NIM - COF 1.151530

$$
\text { - } 0.362349+0.065641 \text { NPATA CAR - GDP } 0.749235-0.749235 \text { INF }
$$

Hypothesis Testing Analysis. Test $\mathrm{T}$ is testing the regression coefficient of each independent variable on the dependent variable to determine how much influence the independent variable on the dependent variable. T-test results are as follows:

Table 6. T-Test Results

\begin{tabular}{l|c|c|c|c}
\hline \multicolumn{1}{c|}{ Variables } & Coefficient & Prob. & Conclusion & Information \\
\hline Constants & 1.487881 & 0.0001 & - & - \\
\hline Bank Size & -0.024388 & 0.0106 & Significant & $\mathrm{H}_{0}$ is rejected \\
\hline Deposits & 0.116992 & 0.5378 & Not significant & $\mathrm{H}_{0}$ is accepted \\
\hline Profitability & -2.215732 & 0.0005 & Significant & $\mathrm{H}_{0}$ is rejected \\
\hline Cost Of Funds & -1.151530 & 0.0009 & Significant & $\mathrm{H}_{0}$ is rejected \\
\hline Asset Quality & -0.362349 & 0.0200 & Significant & $\mathrm{H}_{0}$ is rejected \\
\hline Capital Adequacy Ratio & 0.065641 & 0.6809 & Not significant & $\mathrm{H}_{0}$ is accepted \\
\hline Economic Cycle & -0.749235 & 0.3584 & Not significant & $\mathrm{H}_{0}$ is accepted \\
\hline Inflation & -0.147435 & 0.4015 & Not significant & $\mathrm{H}_{0}$ is accepted \\
\hline Source:
\end{tabular}

Source: (Output Data Eviews 9.0)

Based on the test results of $\mathrm{T}$, then the decision-making is as follows:

(1) Bank Size shows the value of the probability of $0.0106<\alpha 0.05$ that is significant. The value of the coefficient of -0.024388 , This means indicates that there is a negative and significant effect between Bank Size of the Liquidity Risk. The results of this study are consistent with the research that has been carried out which states that bank size has a negative and significant effect on liquidity risk (Sopan and Dutta, 2018). Other studies that support the results of this study carried out in Italy in 675 samples in the bank shows the results of that bank size has a negative effect on the liquidity risk (Giannotti et al., 2010). Large banks are usually able to properly manage their assets such as credit, thereby causing bad loans at the bank to decrease. Thus, the bank also has the potential to reduce the level of liquidity risk (Fola, 2015).

(2) Deposits show the value of the probability of $0.5378>\alpha 0.05$ that is not significant. It is meant to indicate that there is no influence between Deposits on Liquidity Risk. The results of this study are consistent with the research that has been carried out which states that deposits has no effect on liquidity risk (Moussa, 2015). This can occur because the size of the deposit held by the bank does not affect liquidity risk because the bank can manage the deposit so that it can be channeled back to the public so that the bank has sufficient assets to carry out its operational activities and results in the bank not having liquidity risk (Moussa, 2015).

(3) Profitability shows the value of the probability of $0.0005<\alpha 0.05$ that is significant. The value of the coefficient of -2.215732 . This means indicates that there is a negative and significant effect between Profitability on Liquidity Risk. The results of this study are consistent with the research that has been carried out which states found that profitability has a negative and significant effect on liquidity risk (Sopan and Dutta, 2018). 
Other studies that support the results of this study also found that profitability has a negative effect on liquidity risk (Delechat et al, 2014; Sudirman, 2015). Banks that have a high level of profitability tend to be able to meet all the needs of bank liquid assets and can manage these assets properly. So that this thing causes banks to have low liquidity risk (Moussa, 2015).

(4) Cost Of Funds shows the value of the probability of $0.0009<\alpha 0.05$ that is significant. The value of the coefficient of -1.151530 . This means indicates that there is a negative and significant effect between Cost Of Funds to Liquidity Risk. The results of this study are consistent with the research that has been carried out which states that the cost of funds has a negative and significant effect on liquidity risk (Sopan and Dutta, 2018). Other studies that support the results of this study also found that the cost of funds has a negative effect on liquidity risk (Munteanu, 2012). This can be caused because banks need to increase the number of funds from depositors to increase funding costs, so that it can cause banks to be able to channel these funds to borrowers of funds and banks can manage these loan funds properly. Thus, banks can reduce liquidity risk (Singh and Sharma, 2016).

(5) Asset Quality shows the value of the probability of $0.0200<\alpha 0.05$ that is significant. The value of the coefficient of -0.362349 . This means indicates that there is a negative and significant effect between Asset Quality on Liquidity Risk. The results of this study are consistent with the research that has been carried out which states that asset quality has a negative and significant effect on liquidity risk (Sopan and Dutta, 2018). Other studies that support the results of this study also found that asset quality determined based on problem loans and bank liquidity risk has has a negative and significant effect on liquidity risk (Sudirman, 2015; Moussa, 2015; Vodova, 2013). The better the quality of assets owned by banks, the bank has a little bad credit, causing banks to be able to return their funds to depositors and reduce liquidity risk. Whereas banks that have poor asset quality are caused by borrowers unable to pay the funds they borrow and then have an impact on the level of refunds collected by depositors. Therefore, increasing the quality of bad assets can cause banks to experience liquidity risk (Greenidge and Grosvenor, 2010).

(6) Capital Adequacy Ratio shows the value of the probability of $0.6809>\alpha 0.05$ that is not significant. This means indicates that there is no influence between the Capital Adequacy Ratio of Liquidity Risk. The results of this study are consistent with the research that has been carried out which states that capital adequacy ratio had no effect on liquidity risk (Buyuksalvarci and Abdioglu, 2011). Other studies that support the results of this study also found that capital adequacy ratio had no effect against liquidity risk (Shah et al., 2018). This can occur because if the bank meets the minimum capital requirement of $8 \%$, then the bank does not have risks that will occur in the future such as liquidity risk (Bank Indonesia, 2013).

(7) Economic Cycle shows the value of the probability of $0.3584>\alpha 0.05$ that is not significant. This means indicates that there is no influence between Economic Cycle on Liquidity Risk. The results of this study are consistent with the research that has been carried out which states that Gross Domestic Product (GDP) had no effect on liquidity risk (Tseganesh, 2012). This can occur because the high and low levels of the economy in a country only indicate changes in the value of income and expenditure in a country. A person's investment and consumption behavior are influenced by his income, therefore not all income received by a person will be used for savings or investment, but instead is used for consumption (Fola, 2015). 
(8) Inflation shows the value of the probability of $0.4015>\alpha 0.05$ that is not significant. This means indicates that there is no influence between Inflation on Liquidity Risk. The results of this study are consistent with the research that has been carried out which states that inflation has no effect on liquidity risk (Ahmad and Rasool, 2017). Other studies that support the results of this study carried out commercial banks in Namibia shows the results of that inflation has no effect on liquidity risk (Shefeeni and Nyambe, 2016). This is because inflation is a price increase that occurs continuously (Choon et al, 2013). Inflation will cause interest rates to rise. So that the desire of the community to borrow funds from banks is small. Therefore, with the small number of people who want to borrow funds from banks, it can cause banks to have less potential for bad loans (Horváth et al, 2014).

\section{CONCLUSION}

Managerial Implications. Based on the above conclusion, the results of this study provide managerial implications that can be used in business practices for several parties, among others:

Companies. In order to overcome the liquidity risk in a bank then managers need to consider the factors that affect the risk of liquidity such as bank size, profitability, cost of funds, and asset quality by the way; (1) The company should increase the amount of its assets because it shows the level of ability of a company, thus reducing the risk of liquidity. (2) The company should increase its profitability to increase the company's interest income, thus reducing the risk of liquidity. (3) Companies should raise funds from third parties in order to increase the cost of funding, so as to reduce the risk of liquidity. (4) The company should improve its asset quality by increasing the number of loans, thereby reducing the risk of liquidity.

Investor. For investors before investing in a bank, you should pay attention to the level of bank size as seen from the number of its assets. Banks can avoid the risk of liquidity if the bank has good bank profitability by increasing the interest income, as well as adding to the cost of funding. Banks also need to have good asset quality as the basis to look at a bank's liquidity.

Conclusion. This study aims to identify and examine the influence of the independent variable determinant is bank-specific size bank, deposits, profitability, cost of funds, asset quality, capital adequacy ratio and macroeconomic determinants, namely the economic cycle, and inflation on the dependent variable, namely liquidity risk. This study uses 25 commercial banks listed on the Indonesia Stock Exchange in the period 2008-2017. Based on the analysis and discussion that has been done, it can be summed up as follows: (1) Bank size has a negative impact on liquidity risk. Deposits has no effect on liquidity risk. (1) Profitability has a negative impact on liquidity risk. (2) Cost of funds has a negative impact on the liquidity risk. Asset quality has a negative impact on liquidity risk. (3) Capital adequacy ratio has no effect on liquidity risk. (4) Economic cycle has no effect on liquidity risk. (5) Inflation has no effect on liquidity risk.

Research limitations. Based on the results obtained, this research still has some shortcomings and limitations as follows: (1) The samples in this study are limited to the commercial bank listed on the Indonesia Stock Exchange (BEI). (2) Variables used in 
influencing liquidity risk is limited to only size banks, deposits, profitability, cost of funds, asset quality, capital adequacy ratio, the economic cycle, and inflation.

Suggestion. Based on the limited research that has been presented, then this research may provide suggestions for further research in the same field to consider the following: (1) Future studies are expected to not only use a sample Commercial Bank listed on the Indonesia Stock Exchange (IDX) but can add the entire sample bank in Indonesia, including Bank Syariah. (2) Adding other variables as independent variables that can affect liquidity risk as to the interbank rate on the research done by (Choon et al., 2013).

\section{REFERENCES}

Ahmad, F., and Rasool, N. (2017). Determinants of Bank Liquidity: Empirical Evidence from Listed Commercial Banks with SBP. Journal of Economics and Sustainable Development, 8(1), 47-55.

Al-Harbi, A. (2017). Determinants of banks liquidity: evidence from OIC countries. Journal of Economic and Administrative Sciences, 33(2), 164-177.

Al-Khouri, R. (2012). Bank characteristics and liquidity transformation: The case of GCC banks. International Journal of Economics and Finance, 4(12), 114-120.

Al-Kuwari, D. (2009). Determinants of the dividend policy in emerging stock exchange: The case of GCG countries. Global Economy \& Finance Journal, 2(2), 38-63. http://doi.org/10.1108/10942912.2014.917662

Alper, K., Hulagu, T., and Keles, G. (2012). An empirical study on liquidity and bank lending. Central Bank of the Republic of Turkey Working Paper, 4.

Anbar, Adem and Alper, Deger, Bank Specific and Macroeconomic Determinants of Commercial Bank Profitability: Empirical Evidence from Turkey (April 20, 2011). Business and Economics Research Journal, Vol. 2, No. 2, pp. 139-152, 2011.

Arif, A., and Nauman Anees, A. (2012). Liquidity risk and performance of banking system. Journal of Financial Regulation and Compliance, 20(2), 182-195.

Bank for International Settlements (2009). Enhancements to the Basel II framework. Retrieved from https://www.bis.org/publ/bcbs157.pdf.

Berger, A. N., and Bouwman, C. H. (2009). Bank liquidity creation. The review of financial studies, 22(9), 3779-3837.

Bhati, S., DeZoysa, A., and Jitaree, W. (2015). Determinants of liquidity in nationalised banks of India. In World Finance \& Banking Symposium (pp. 1-11).

Bonfim, D., and Kim, M. (2011). Liquidity risk in banking: is there herding?. European Banking Center Discussion Paper, 24, 1-31.

Bonner, C., Lelyveld, I. van, and Zymek, R. (2014). Banks' Liquidity Buffers and the Role of Liquidity Regulation. Journal of Financial Services Research, 48(3), 215234.doi:10.1007/s10693-014-0207-5

Bordeleau, É., and Graham, C. (2010). The impact of liquidity on bank profitability (No. 2010, 38). Bank of Canada working paper.

Buyuksalvarci, A. and Abdioglu, H., (2011). Determinants of Capital Adequacy Ratio in Turkish Banks: A Panel Data Analysis. African Journal of Business Management, 5(27) : $11199-11209$.

Choon, L. K., Hooi, L. Y., Murthi, L., Yi, T. S., and Shven, T. Y. (2013). The determinants influencing liquidity of Malaysia commercial banks, and its implication for relevant 
bodies: evidence from 15 Malaysian commercial banks. Universiti Tunku Abdul Rahman, Kampar.

Cucinelli, D. (2013). The determinants of bank liquidity risk within the context of euro area. Interdisciplinary Journal of Research in Business, 2(10), 51-64.

Deléchat, C., Henao Arbelaez, C., Muthoora, P., and Vtyurina, S. (2014). The determinants of banks' liquidity buffers in Central America.

Dinger, V. (2009). Do foreign-owned banks affect banking system liquidity risk?. Journal of Comparative Economics, 37(4), 647-657.

Fola, B. (2015). Factors affecting liquidity of selected commercial banks in Ethiopia (Doctoral dissertation, $\mathrm{PhD}$ thesis, Addis Ababa University, Addis Ababa).

Ghadia, M., Nayan. (2015). "A Study Of Asset Quality of Selected Public \& Private Sector Banks in India”. International Journal of Applied Research, Vol. 12, pp 270-274.

Giannotti, C., Gibilaro, L., and Mattarocci, G. (2011). Liquidity risk exposure for specialised and unspecialised real estate banks: Evidence from the Italian market. Journal of Property Investment \& Finance, 29(2), 98-114.

Greenidge, K., and Grosvenor, T. (2010). Forecasting non-performing loans in barbados. Journal of Business, Finance \& Economics in Emerging Economies, 5(1).

Horváth, R., Seidler, J., and Weill, L. (2014). Bank capital and liquidity creation: Grangercausality evidence. Journal of Financial Services Research, 45(3), 341- 361.

Kasmir. (2015). Dasar-Dasar Perbankan. Edisi Revisi 2014. PT Raja Grafindo: Jakarta.

Lartey, V. C., Antwi, S., and Boadi, E. K. (2013). The Relationship Between Liquidity And Profitability Of Listed Banks In Ghana. International Journal of Business and Social Science, 4(3).

Lei, A. C. H., and Song, Z. (2013). Liquidity Creation And Bank Capital Structure In China. Global Finance Journal, 24(3), 188-202.doi:10.1016/j.gfj.2013.10.004

Menicucci, E., and Paolucci, G. (2016). The Determinants Of Bank Profitability: Empirical Evidencefrom European Banking Sector. Journal of Financial Reporting and Accounting, 14(1), 86-115.

Moussa, M. A. B. (2015). The determinants of bank liquidity: case of Tunisia. International Journal of Economics and Financial Issues, 5(1), 249-259.

Munteanu, I. (2012). Bank Liquidity and its Determinants in Romania. Procedia Economics and Finance, 3, 993-998. doi:10.1016/s2212-5671(12)00263-8.

Ogege, S., Williams, H., and Emerah, A. (2012). An Empirical Analysis Of Capital Adequacy In The Banking Sub-Sector Of The Nigeria Economy. International Journal of Economics and Finance, 4(5), 208.

Olalekan, A., and Adeyinka, S. (2013). Capital adequacy and banks' profitability: an empiricalevidence from Nigeria. American International Journal of Contemporary Research, 3(10), 87-93.

Painceira, J. P. (2010). The Role Of Banks In The Korean Financial Crisis Of 1997: An Interpretation Based On The Financial Instability Hypothesis. In Minsky, Crisis and Development (pp. 302-317). Palgrave Macmillan, London.

Parameswar, N., and Murthy, S. R. (2012). The Determinants of Bank Liquidity during Financial Crisis: A Comparative Study of the GCC Banking Industry. Journal of Academy of Business and Economics ${ }^{\mathrm{TM}}, 12(3), 10$.

Peraturan Bank Indonesia Nomor 15 / 12 / PBI / (2013) tentang Kewajiban Penyediaan Modal Minimum Bank Umum. 
Rauch, C., Steffen, S., Hackethal, A., and Tyrell, M. (2010). Determinants of bank liquidity creation. Available at SSRN 1343595.

Reserve Bank of India (2012, November). Liquidity Risk Management by Banks.

Said, A. (2018). Effect of the Asset Quality on the Bank Profitability: A Study of US Commercial Small Banks. International Research Journal of Applied Finance, 9(4), 196-204.

Shah, S. Q. A., Khan, I., Shah, S. S. A., and Tahir, M. (2018). Factors Affecting Liquidity of Banks: Empirical Evidence from the Banking Sector of Pakistan. Colombo Business Journal, 9(1).

Sheefeni, J. P., and Nyambe, J. M. (2016). Macroeconomic Determinants Of Commercial Banks' Liquidity In Namibia. European Journal of Business, Economics and Accountancy, 4(5), 19-30.

Singh, A., and Sharma, A. K. (2016). An Empirical Analysis Of Macroeconomic And BankSpecific Factors Affecting Liquidity Of Indian Banks. Future Business Journal, 2(1), 40-53.

Sopan, J., and Dutta, A. (2018). Determinants of Liquidity Risk in Indian Banks: A Panel Data Analysis.

Sudirman, I. (2015). Determinants Of Bank Liquidity In Indonesia: Dynamic Panel Data Analysis. In 11th International Annual Symposium On Management, The Singhasari Resort, Batu, Malang, Indonesia. DOI10 (Vol. 2139).

Trenca, I., Petria, N., and Corovei, E. A. (2015). Impact Of Macroeconomic Variables Upon The Banking System Liquidity. Procedia Economics and Finance, 32, 1170-1177.

Tseganesh, T. (2012). Determinants Of Banks Liquidity And Their Impact On Financial Performance: empirical study on commercial banks in Ethiopia.

Vodova, P. (2011). Liquidity of Czech commercial banks and its determinants. InternationalJournal of mathematical models and methods in applied sciences, 5(6), 1060-1067.

Vodová, P. (2013). Determinants of commercial bank liquidity in Hungary. e-Finanse: Financial Internet Quarterly, 9(3), 64-71.

Wójcik-Mazur, A., and Szajt, M. (2015). Determinants of liquidity risk in commercial banks in the European Union. Argumenta Oeconomica, (2 (35)), 25-47.

Yulita, A., and Pangestuti, I. R. D. (2014). Analisis Pengaruh Faktor Makroekonomi Terhadap Tingkat Kredit Bermasalah Pada Bank Umum Di Indonesia.

www.bi.go.id

www.bps.co.id

www.idx.co.id 